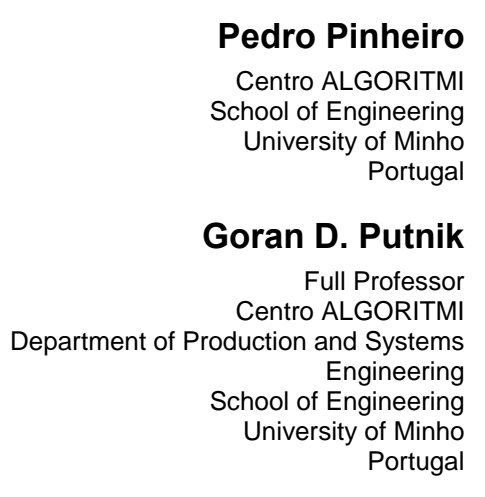

Pedro Pinheiro

ALGORITM

ool of Engineering

Portugal

Dutnik

GORITMI

Portugal

\title{
Organizational Efficiency Prospects for Management in Industry 4.0
}

Industry 4.0 emerges as a tool to help organizations manage. Often identified with the Internet of Things and Cyber-Physical Systems, Industry 4.0 appears as a solution to many of the difficulties plaguing manufacturing. The history of management theories, e.g. by Taylor, Fayol, or Simon, shows that deterministic solutions do not ensure the permanent success of organizations. In manufacturing, the economy overlaps the technological, social, environmental, and cultural dimensions that influence organizations.

This paper assesses the possible benefits for the efficiency of the organizations resulting from the implementation of Industry 4.0. To fulfill this purpose, the effects on the hierarchical structures of organizations are investigated, namely those related to specialization, authority, and span of control.

The results show that technological advances and efficiency of industry 4.0, which are relevant for the economy, still do not respond satisfactorily to social needs that require changes in the behavior of the management system.

Keywords: management, Industry 4.0, efficiency, hierarchy, specialization, decision-making process, span of control.

\section{INTRODUCTION}

The hypothetical fourth industrial revolution sustained in industry 4.0 predicts a qualitative change in the manufacturing systems, characterized by digitization, extensive and intelligent integration of processes, and self-organization [1]. Industry 4.0 represents an emerging context for industrial activities, where physical equipment, control processes, and supporting information systems are closer than ever [2]. The growing digitalization of manufacturing systems and the necessary integration of Cyber-Physical Systems (CPS) unveil new challenges to the management of organizations. CPS, is considered by some authors as interconnected parts in each part and process, and the system itself must have the ability to change its behavior to adapt to changing requirements [3]. By other authors, CPS is a control system with "feedback loops where physical processes affect computations and vice versa", cited in [2].

In management, the pyramid figure still predominates, showing a military organizational structure centered on function. However, Peter Drucker [4] warned that this type of structure kills ideas in organizations with high technology and advanced knowledge.

The manufacturing needs to understand that human organizations can adapt and evolve and thus create a new order and coherence. The emergence of a new order and coherence is one of the foundations of complexity and allows for new ways of working,

Received: January 2021, Accepted: September 2021

Correspondence to: Pedro Pinheiro

ALGORITMI Research Center, University of Minho Campus of Azurém, 4800-058 Guimarães. Portugal

E-mail: pedro.tele9@gmail.com

doi:D10.5937/fme2104773P

(C) Faculty of Mechanical Engineering, Belgrade. All rights reserved forming new relationships, and favoring the emergence of new structures [5].

The purpose of the paper is to examine the efficiency of organizational structures, including those associated with Industry 4.0. It is possible to apply the proposed models to all CPS, except for systems that use collaborative engineering, because they have characteristics beyond the paper's scope. Thus, the suggested models have only a restricted application to systems related to sequential engineering (SeqE), simultaneous engineering (SE), concurrent engineering (CE). The $\mathrm{SeqE}, \mathrm{SE}$, and $\mathrm{CE}$, as defined in [6], share a management goal that is a kind of "efficiency" that has coordination that "implies the common goal of (members) of the engineering/project team."

The CPS includes humans and "things"; therefore, the formulas presented apply to these two types of agents. When the example of a network is composed only of people, it is also possible to extrapolate to the behalvior of the dominant CPS in industry 4.0. Then the models could be applied to sensors in an "Internet of Things," isolated or integrated into the CPS. This simplification was intended only not to add unnecessary noise to the presentation of the model.

Since efficiency prevails as one of the main goals in managing organizations and continues to be prominent in Industry 4.0, the second chapter looks at the concept of efficiency in a different approach to mainstream science. The objective is to reinterpret some older conceptual frameworks, such as those by Farrel [7] and Ricardo [8], transposing them to the new reality of industry 4.0 .

In the third chapter, we present the equations that assess the effects on efficiency caused by specialization, authority, and span of control of organizational hierarchies. These models are validated in the fourth 
chapter and acknowledge the need for more detailed analysis for industry 4.0 concerning the decisionmaking process and efficiency.

Our results indicate that the impacts of technological changes are decisive in the lower hierarchical layers of organizations. The results also show that, for the same number of hierarchical levels, large organizations in terms of efficiency are likely to obtain better performance when compared to smaller ones.

These values cannot be dissociated from a horizontal integration of the new agents into the new structures, nor from the authority capabilities held by the organizations. In other words, this means that models aren't context-sensitive, i.e., aren't susceptible to human behavior in organizational structures. This last claim is elaborated in the fourth chapter.

\section{EFFICIENCY}

The concept of efficiency creates a relationship in a transformation process that results in a product or service (output) from a set of variables (inputs). This quotient, considering different dimensions and qualities, has always been associated with uncertainty. The unit conversion precept often ignores context. In other words, efficiency considers only the system's internal attributes, and the attribution of average values eliminates the particular dimensions, like time. Energy efficiencies imbibe time in their magnitude. In other cases, the temporal dimension appears only indirectly and is considered an external attribute. For example, a system that locally concentrates all manufacturing phases for a product, compared to piecemeal production, is involved in a different uncertainty of raw material logistics and customer deliveries. While fragmented production entails higher logistical costs and a diverse cultural context that generates much more uncertainty, a circumscribed culture reduces the capacity for change and transformation. However, the calculation of efficiencies generally does not consider these structural logistical constraints that indirectly expose the time variable.

When referring to hierarchical structures and the division by function of its members, the lower layers of the pyramid are responsible for manual work, requiring only the concept of efficiency that reports the savings in quantity and quality of what is produced [9]. On the other hand, if the intention is to assess the action and social concern of the organization's top management, efficiency is not crucial.

The idea of efficiency is widespread in engineering. It provides a very accurate assessment of the mechanical and energetic behavior of systems. Nevertheless, the diffusion of efficiency to other areas poses problems of cohesion. When the system has numerous inputs from different sources and variables, efficiency cannot be accurately determined. For example, Farrell [7] proposed that organizations calculate their efficiency based on the best performance of similar organizations, e.i., efficiency would be the ratio between the current result and a standard. Of course, with evolution, the pattern changes. However, when referring to the structure of higher output production for a given combination of inputs in organizations that share a similar technology [10], this efficiency is impossible to calculate in the absence of a reference as in the case of new realities that emerge.

From the concept of structural efficiency developed by Farrell came the idea of decision-making units that analyze mutual products and inputs that assess the processes of different organizations [11]. Due to their particularities, these decision units are more suitable for public sector companies that, being averse to change, provide a large amount of data.

The improvement in efficiency has been strongly manifested in the management of the economy of organizations because its tenet makes it possible to increase production without absorbing more resources [7, 12]. It is important to emphasize that only viable circumstances support Farrell's concept of efficiency and decision-making units, and these realities are different from ideal theoretical situations [13].

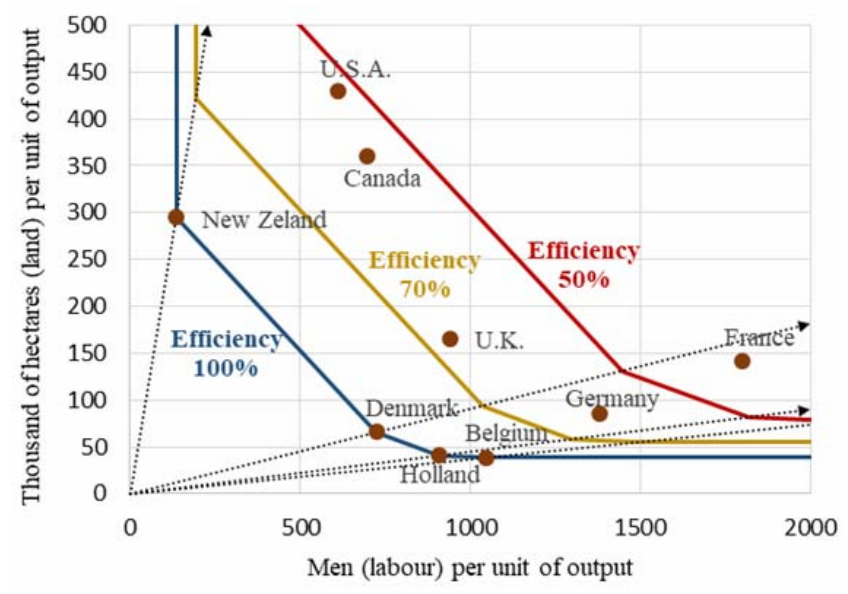

Figure 1: Application of the efficiency proposed by Farrell for agricultural production, adapted from [7].

The approach proposed by Farrell does not mitigate the generic problems of the concept of efficiency in the theory of organizations, as it ignores the consequences of the methods used in production, namely the environmental, social, or cultural impacts. In Farrell's realistic assessment, evanescent economic gains continue to predominate. The success of organizations remains an egocentric, competitive, fallacious measure that restricts solutions when supported only by economic efficiency.

Management's fascination with the efficiency of organizations can have surprisingly adverse effects, as demonstrated by the rewards arising from the efficiency that tend to aggravate inequality as efficiencies increase. Efficiency comes at a price and can increase the risk of social disorder [14]. Furthermore, using the same argument as David Ricardo [8] in the 19th century, Martin [14] emphasizes the importance of the observation that it was "more efficient for Portuguese workers to make wine and English workers to make cloth, each group would be better off focusing on its area of advantage and trading with the other." Note that Martin's concept of efficiency includes the productive context, which the traditional idea of efficiency ignores. Therefore, it becomes convenient for organizations to focus more resources on other competitive advantages, such as resilience. It follows that "an extreme local weather 
event or a pernicious virus could destroy most of the world's production" [14].

Market rivalry tells us that many of the ubiquitous factors in the supply chain receive only cursory attention with offshoring, which creates significant competitive risk for the organization in times of scarcity [15]. In these cases, the concept of efficiency is insufficient to assess different realities that, such as offshoring and reshoring, can result in other productions of the same product or service.

Figure 2 reveals the contradictions that result from crises. The opportunism of the price adjustment led to the creation of a self-organized system that initially had a disastrous effect on the price of protective masks when the SARS-CoV-19 pandemic began. However, the final result set a price $33 \%$ lower than the original price (3 Yuan, or US\$0,4, for the N95 mask and 0,5 Yuan, or US\$0,07, for the disposable medical mask) [16].

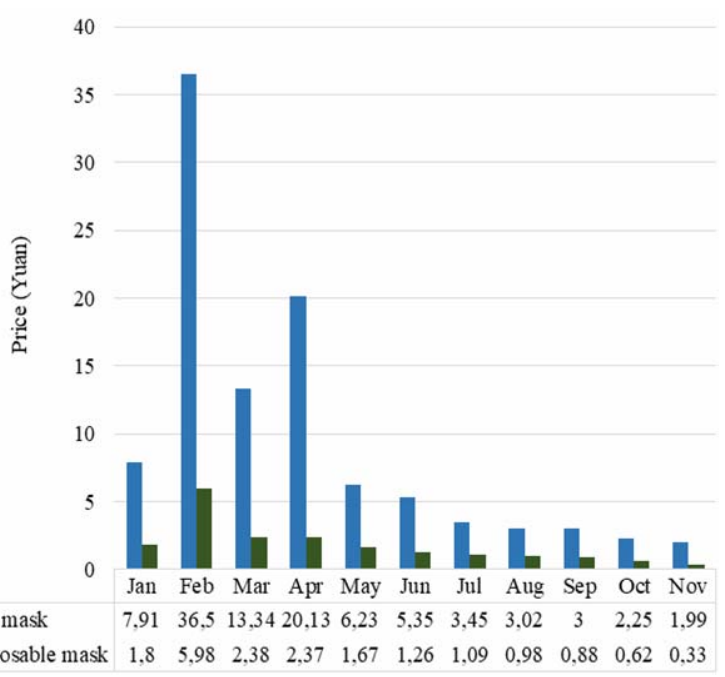

Figure 2: Changes in the price of face masks in 2020, adapted from [16].

\section{PROPERTIES OF ORGANIZATIONAL STRUC- TURES ON EFFICIENCY}

The complexity of human social controls requires restrictions. The organization can consume itself in its bureaucracy if there are too many restrictions with too many details and hierarchical levels, whereas the absence of constraints can render the system function useless and on the verge of anarchy. Hierarchical controls arise due to the degree of internal restriction that forces the elements to a simple collective behavior, i.e., independent of the individual dynamic behavior. It is emphasized again that a hypothetical ideal level of restriction cannot be precisely specified but lies between the extremes of strict determinism and stochastic chaos. It is significant that the concept of "autonomy" or "freedom" restricts itself to behavior between these extremes and develops by adding and removing restrictions [17].

As reality settles between the utopias of total control and the absence of control, we defend that all organizations work in a hybrid way that simultaneously contains the properties of open systems and closed systems. In the ambiguity of hybridity, a combination of organizational design archetypes stands out [18]. Ambiguity emphasizes the tendency of complex structures to be scale-invariant and exhibit a dilation that can apply all scales of an individual to an entire system [5]. The perception of homothety, from Greek $\mu o$ (same) plus $\theta \dot{\varepsilon} \sigma l \varsigma$ (position), depends on the observer's focus, the limits of the domain he defined, and his set of interests, i.e., it depends on the definition of the context [19]. The homothety present in Farrell's concept of efficiency discovers that all efficiency values refer to a pattern, which only transforms when the paradigms that support it change.

Despite the inherent introduction of inefficiencies, the manufacturing processes proposed by Industry 4.0 cannot exclude the hierarchical organization. All systems, up to Big Data and Artificial Intelligence, lack compression of information to support decision-making. In any organization, the management of these selection processes depends on decomposing social network data into clusters and forming the corresponding hierarchical organizational structure [20]. The challenge in organizations is to discern the truth in a context where elements have conflicting goals, and there can be a deliberate distortion of the information circulating in the system. Thus, the need for specific heuristic processes of simplification and semantic transformation allows the emergence of knowledge that improves the quality of the decision.

The inevitable incomplete observation of the system creates uncertainties, makes it difficult to understand the organization, and worsens communication and interaction between individuals. Organizations must increase contributions and observation points to decrease uncertainties and accurately compute them. However, we do not defend the collaboration that results from a consent process but a conscious integration. An acquiescent management does not promote learning.

The creation and acceptance of proverbs are perennial, even in science that uses them as commandments. Herbert Simon [21] investigated some of Fayol's [22] administrative efficiency principles, namely, that organizational efficiency is dependent on specialization, the exclusivity of authority, and a limited command scope. However, it is possible to refute these three principles:

a) Specialization designates not only function but location as well. Since it is not possible for two people to do the same thing in the same place at the same time, the notion of efficiency through specialization is subjective because two people are always doing different things [21].

b) The concept of authority requires the subordinate to change his behavior regardless of his assessment of the decision's merit. Thus, in the absence of virtuous choices, the principle of a single authority, besides weakening efficiency by the entropic effect of time, always has a lower certification than a collegiate decision as long as it has an odd number of elements. On the face of it, a single authority can make judgments quickly but not more efficiently.

c) While limiting the number of subordinates per foreman is beneficial to the organization's efficiency; on the other hand, as an organization grows, it inevitably increases the number of hierarchical levels, which decreases the overall efficiency of the system. 


\subsection{Specialization}

Specialization increases the need for cooperation between people and between people and machines, forces the creation of groups, and increases the complexity of systems. The existence of teams depends on ethical compliance and may not advocate better results [23]. In management, the term synergy is often a myth.

Specialization itself does not increase the number of hierarchical levels; it can only make them more complex.

In the case of Industry 4.0, the horizontal integration of "things" replaces or assists existing parts at a given hierarchical level. Ultimately, the overall efficiency of an organization's elements depends on the type of integration. In horizontal integration, the efficiency $\left(E_{h}\right)$ of $n$ elements, individually with an efficiency $E_{h i}$, and a productivity factor $x_{i}$, where the sum of $x_{i}$ is equal to 1 , can result in (1) if the processing at this hierarchical level is parallel for different products or services.

$$
E_{h}=\sum_{i=1}^{n} x_{i} E_{h i}
$$

For example, consider the contribution $\left(x_{2}\right)$ of a robot to a given operation that was previously performed only by the work of one person $\left(x_{1}\right)$. The new total system $E_{h}$, in (2), integrates the robot efficiency $\left(E_{2}\right)$ and the efficiency of the previous human work $\left(E_{l}\right)$.

$$
E_{h}=x_{1} E_{1}+x_{2} E_{2}
$$

As the efficiency and production capacity of the machine is superior to the previous values of exclusively human work, the new total operational efficiency will be close to the value of the robot. Hence the justification for the horizontal integration of cybernetic automatisms in systems, to increase the quantity and quality of production.

However, we must be aware of the perverse effects that increased production can have on the economy. The horizontal integration of things in manufacturing will have a higher impact on productivity than on efficiency. As $x_{2}$ is much larger than $x_{1}$, the sharp rise in production has to be absorbed by the economy. The complexity of the new products will use up some surplus, but the economy has to include the rest, which, due to constant competition, could end up in overproduction. Note that this was one of the reasons for the Great Depression of 1928 (which manifested itself in the October 1929 stock market crash). The risks may come from the slowdown in population rise and the reduction in the consumption of people who do not keep up with the growth of production. While Industry 4.0 can predict manufacturing gains, it can also have catastrophic consequences on the economy and society.

As shown in (3), as serial processing, the efficiency of vertical integration $\left(E_{v}\right)$ results from the product of the efficiencies $\left(E_{v i}\right)$ of each of the $n$ hierarchical levels.

$$
E_{v}=\prod_{i=1}^{n} E_{v i}
$$

If the integration of cybernetic automatisms requires new hierarchical levels without changes in the organi- zational structure, the new total efficiency would always be lower than that of the original system.

Although it does not exclude Simon's argument, the integration of the "things" of Industry 4.0 must be horizontal and parallel so as not to compromise the control of the changes made, since the vertical integration of a new level only fits into the (2). Management must recognize the impact of individual novelties to admit potential synergies. Controlling an integral vertical split requires a new standard, i.e., meaning it belongs to another organization.

Management can model it, but remember Tsyganov's [24] that one of the biggest problems in adopting any innovation in an organization is the impossibility of strategic management to consider all the adversities that only production personnel know during the change process. Ignorance not only increases the "risks, costs and time of innovation, but also makes adaptive identification algorithms ineffective."

\subsection{Authority}

In his analysis of the "Shop Management" [25], Fayol [22] agrees with Taylor [25] on the need to strengthen chiefs and foremen with a General Staff but disagrees when Taylor doubts the virtues of "military-type" organizations, denies the principle of the command unit, and admits a worker under the orders of two masters. Despite his admiration for Taylor's work, Fayol does not relinquish the principle of unity of command, and while he acknowledges that it may have worked because of Taylor's skill, he doesn't believe in the merits of violating that principle.

We can check if two chiefs $\left(\mathrm{C}_{1}, \mathrm{C}_{2}\right)$ who command the same subordinate (S) improve the accuracy of orders. Table 1 shows the result of a similar accuracy of chiefs' orders. In this case, they have a $95 \%$ probability (p) of getting it right.

Table 1. Effect on the quality of a decision in the case of a subordinate headed by two chiefs with preference of one chief $\left(C_{1}\right)$, in the case of tie.

\begin{tabular}{|c|c||c||c||c|c|c|}
\hline $\mathrm{C}_{1}$ & $\mathrm{C}_{2}$ & $\mathrm{~S}$ & Result & \multicolumn{3}{|c|}{ Probability of occurrence of an event } \\
\hline 0 & 0 & 0 & Unwanted & $0,05 \times 0,05=$ & 0,0025 & \multirow{2}{*}{$5 \%$} \\
\hline 0 & 1 & 0 & Unwanted & $0,05 \times 0,95=$ & 0,0475 & \\
\hline 1 & 0 & 1 & Wanted & $0,95 \times 0,05=$ & 0,0475 & \multirow{2}{*}{$95 \%$} \\
\hline 1 & 1 & 1 & Wanted & $0,95 \times 0,95=$ & 0,9025 & \\
\hline
\end{tabular}

0's mean a wrong decision while 1's a good one.

Table 1 reports that the subordinate, in case of a tie, prefers the $\mathrm{C}_{1}$. However, the result would be the same if the subordinate had a purely random behavior of $50 \%$ preference for each of his chiefs. The probability of getting each chief's verdict right is equal. Therefore, mathematically, it results in the same values in case of a tie of contradictory orders. It is also noteworthy that the subordinate behaves like an unconscious actuator that responds to binary decisions.

The result corroborates the saying: "A man with one watch knows what time it is. A man with two watches is never sure" [26]. The proverb, like table 1, highlights that management must reject that more and better are synonymous. 
The human organization, which, due to its adaptability and interactivity characteristics, integrates the most complex category known as the self-organized system, reminds us that there are no completely hierarchical organizations. Aware of this situation, the desire to classify the interacting elements of complex systems can constrain the flexibility and adaptive fitness characteristic of self-organized systems [27].

We have previously recognized that self-centered interpretations influence the perception of the environment and, consequently, justify that communication, negotiation, and other similar pragmatic instruments occur in the implementation of CE [28]. The result in table 1 depends on the human capacity for change. It applies to things like sensors embedded in a network or people who behave like machines.

Deterministically, with chiefs with different abilities and hit probabilities, the most capable element of the group anchors the highest result in the case of a duality. However, with dialogue and collaboration, faced with the inevitable disagreements of complex situations, the result can be better than provided by the best chief. Taylor [25], according to Fayol [22], promoted and achieved this.

Table 2 shows the improvement in the result of the system when the subordinate receives orders from three chiefs who, equally, have a $95 \%$ probability of success in decisions they make.

Table 2. Effect on the quality of a decision in the case of a subordinate headed by three chiefs.

\begin{tabular}{|c|c|c|c|c|c|c|}
\hline $\mathrm{C}_{1}$ & $\mathrm{C}_{2}$ & $\mathrm{C}_{3}$ & $\mathrm{~S}$ & Result & \multicolumn{2}{|c|}{$\begin{array}{c}\text { Probability of occurrence of an } \\
\text { event }\end{array}$} \\
\hline 0 & 0 & 0 & 0 & Unwanted & 0,000125 & \multirow{4}{*}{$0,725 \%$} \\
\hline 0 & 0 & 1 & 0 & Unwanted & 0,002375 & \\
\hline 0 & 1 & 0 & 0 & Unwanted & 0,002375 & \\
\hline 1 & 0 & 0 & 0 & Unwanted & 0,002375 & \\
\hline 0 & 1 & 1 & 1 & Wanted & 0,045125 & \multirow{4}{*}{$99,275 \%$} \\
\hline 1 & 1 & 0 & 1 & Wanted & 0,045125 & \\
\hline 1 & 0 & 1 & 1 & Wanted & 0,045125 & \\
\hline 1 & 1 & 1 & 1 & Wanted & 0,857375 & \\
\hline
\end{tabular}

Although the quality of decision enforcement has improved with three chiefs, we must be cautious as the argument that people are not machines remains. The dynamism of human systems and egos can make this assumption inconsistent. Hence the importance of ethics and behavior in organizations, from top to bottom.

With the notions presented in tables 1 and 2 and considering $n$ the number of chiefs per subordinate, $p$ the probability of accuracy of the single decision and $P$ the probability of accuracy of the decision made by $n$ chiefs, we arrive at (4) and (5).

If $\mathrm{n}$ is an odd number:

$$
P_{n}=\sum_{i=\frac{n+1}{2}}^{n} \prod_{j=0}^{i-1} \frac{n-j}{j+1} p^{i}(1-p)^{n-i}
$$

If $\mathrm{n}$ is an even number $P_{n}=P_{n-1}$, or:

$$
\begin{aligned}
& P_{n}=\sum_{i=\frac{n}{2}}^{n} \prod_{j=0}^{i-1} \frac{n-j}{j+1} p^{i}(1-p)^{n-i} \\
& -\frac{1}{2} \prod_{j=0}^{\frac{n-2}{2}} \frac{n-j}{j+1} p^{\frac{n}{2}}(1-p)^{\frac{n}{2}}
\end{aligned}
$$

For the reasons indicated in table 1, the second part of (5) disregards half the value in tie situations. Such a situation, humanly, as we have already mentioned, can be overcome.

In (4) and (5), we use the same probability of hit decision for all managers. Although this is a simplification, we assume that, over time, systems tend to be homogeneous, creating stability until they reveal inconsistencies. The good tends to be associated with good and inept to be associated with inept, and systems tend to balance each other, implies similar probabilities of success for board members in the decision-making process.

Table 3 contains some values that show the impact of orders arising from collective decisions.

\begin{tabular}{|c|c|c|c|c|c|c|c|}
\hline & \multicolumn{7}{|c|}{ Number of chiefs per subordinate } \\
\hline & 1 & 2 & 3 & 4 & 5 & 6 & 7 \\
\hline \multirow{6}{*}{ 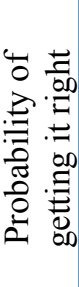 } & 0,95 & 0,95 & 0,99275 & 0,99275 & 0,99884 & 0,99884 & 0,99981 \\
\hline & 0,90 & 0,90 & 0,97200 & 0,97200 & 0,99144 & 0,99144 & 0,99727 \\
\hline & 0,80 & 0,80 & 0,89600 & 0,89600 & 0,94208 & 0,94208 & 0,96666 \\
\hline & 0,70 & 0,70 & 0,78400 & 0,78400 & 0,83692 & 0,83692 & 0,87396 \\
\hline & 0,50 & 0,50 & 0,50000 & 0,50000 & 0,50000 & 0,50000 & 0,50000 \\
\hline & 0,30 & 0,30 & 0,21600 & 0,21600 & 0,16308 & 0,16308 & 0,12604 \\
\hline
\end{tabular}

Table 3. Accuracy in decisions made by a collective of $\mathbf{n}$ elements that have an individual accuracy of $95 \%$.

There is symmetry at $\mathrm{p}=0,5$ in the discrete distribution resulting from (4) and (5), as observed, e.g., for $\mathrm{p}=0,3$ and $\mathrm{p}=0,7$. In random decisions, randomness remains.

The graph represented in Figure 3 visually summarizes these features (symmetry, rapid inflections, and the neutral effect of groups with an even number of elements).

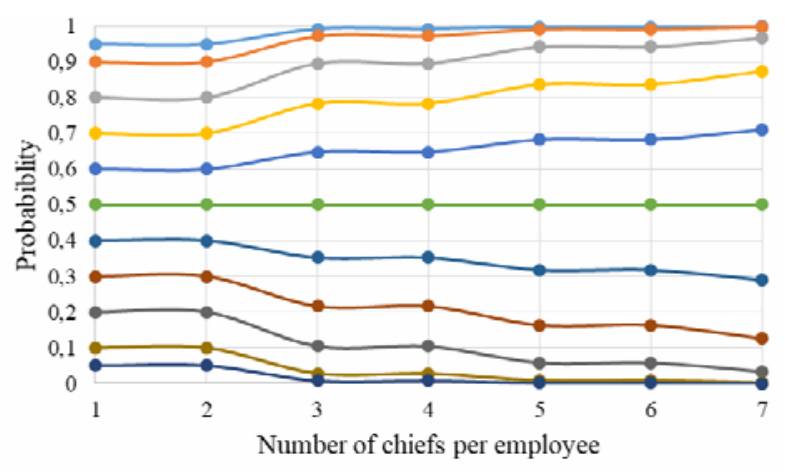

Figure 3: Effects of the number of elements in the quality of a decision-making process.

Figure 4 shows how, graphically, a collective decision of four members results. In the representation of $p$ is the accuracy of individual choice, and $\mathrm{q}$ is equal to $1-p$. 
Problem (start of

the decision-making process)

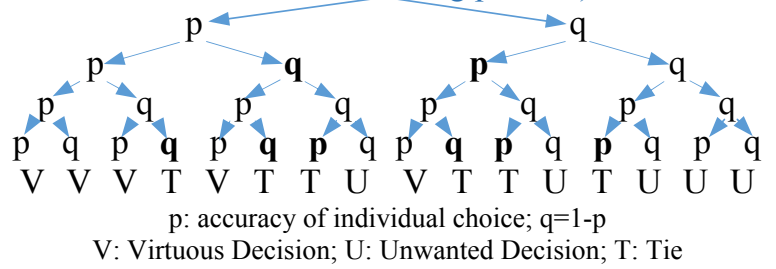

Figure 4: Efficiency of a group of 4 decision-making elements.

Events marked with a bold letter represent the tie situations.

Figure 4 confirms the existence of a homothety, a symmetry, and binomial expansion with hierarchical (flagged in the product) and heterarchical (flagged in the sum) characteristics present in tables 1 and 2 and (4) and (5).

\subsection{Hierarchy efficiency}

Until now, the concern was at the top of the hierarchy of organizations. This section looks at the effect of power relations at the bottom.

One of the characteristics of hierarchical levels is the number of subordinates assigned to each chief. However, at the bottom of the organization, the foremen usually commands a higher proportion of workers. In the hierarchical structure shown in Figure 5, each foreman commands six workers. At the following levels, there is a ratio of four subordinates to each leader.

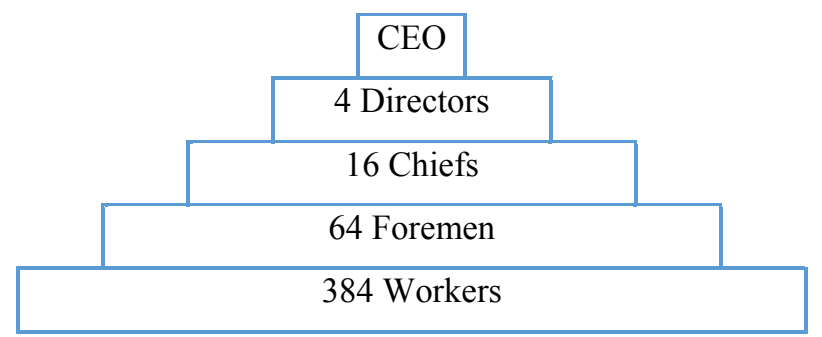

Figure 5: Example of an organization's hierarchical structure

In this example, the total number of base workers $\left(T_{w}\right)$ in the organization is 384 , the total number workers $(T)$ is 468 , excluding the top level of CEO.

The total number of workers is a geometric distribution [22].

$$
T_{w}=w c^{n}
$$

The proportion of workers per foreman, or span of control in the bottom of the hierarchy $(w)$ is the initial value, $n$ is the number of leadership levels, excluding the top level of $\mathrm{CEO}$, and $c$ is the common ratio between leaders.

From (6), we can calculate the ratio between the number of workers present in the base and the total number of people in the organization, which we call hierarchy efficiency $\left(E_{H}\right)$.

$$
E_{H}=\frac{T_{w}}{T}=\frac{w c^{n}}{w c^{n}+\sum_{i=1}^{n} c^{i}}
$$

Since, rationally, the number of chiefs is less than the number of workers at the bottom, $E_{H}$ is limited.

$$
\frac{w}{w+1} \geq E_{H}>\frac{w}{w+2}
$$

Keeping the same ratio at the bottom of the hierarchical structure shown in figure 5, i.e., six workers per foreman, we can build, with (7), the table 4 .

Table 4. Hierarchy efficiency in organizations with $w=6$, a

\begin{tabular}{|c|c|c|c|c|c|}
\hline & & \multicolumn{4}{|c|}{$\begin{array}{l}\text { Number of subordinates assigned to each chief at } \\
\text { the top of the hierarchy }\end{array}$} \\
\hline & & 2 & 3 & 4 & 5 \\
\hline \multirow{6}{*}{ 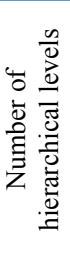 } & 2 & 0,857143 & 0,857143 & 0,857143 & 0,857143 \\
\hline & 3 & 0,800000 & 0,818182 & 0,827586 & 0,833333 \\
\hline & 4 & 0,774194 & 0,805970 & 0,820513 & 0,828729 \\
\hline & 5 & 0,761905 & 0,801980 & 0,818763 & 0,827815 \\
\hline & 6 & 0,755906 & 0,800659 & 0,818327 & 0,827632 \\
\hline & 7 & 0,752941 & 0,800220 & 0,818218 & 0,827595 \\
\hline
\end{tabular}
different number of hierarchical levels and ratios of headship.

As two hierarchical levels consider only workers and foremen, the value of $E_{H}$ is the same, as chiefs only make up the structure above the second level. The value of $E_{H}$ is the higher limit revealed in (7), i.e., 6/7. For this example, using (8), the minimum value of $E_{H}$ is $6 / 8$ $(75 \%)$.

Table 4 also shows that the best $E_{H}$ results are on the right side, although the improvement is insignificant when organizations go beyond four hierarchical levels. However, we must be aware that, usually, only large companies have more than four levels. In addition to the context benefits, they also benefit from its structure.

Through (8), it is possible to obtain the graph on figure 6 that shows the limits of the relationship between hierarchy efficiency and span of control. The higher the hierarchy efficiency value has, the broader the span of control values will be, which is interlinked with the Promethean's desire to reduce hierarchical layers. However, the solution is not simple.

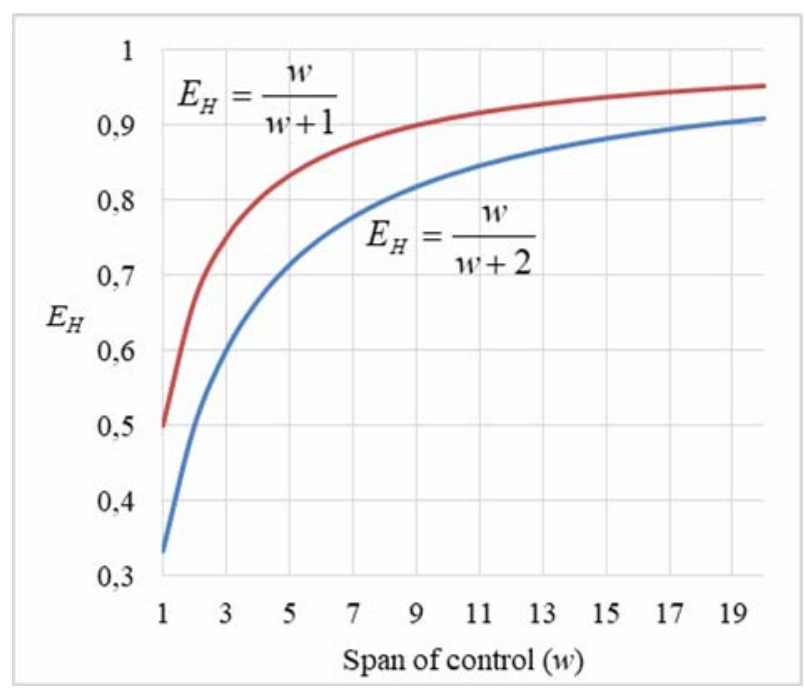

Figure 6: The dependence of the hierarchy efficiency on the span of control. Obtained by the interval of (8).

From (8), we can compute (9). 


$$
\frac{E_{H}}{1-E_{H}} \leq w<\frac{2 E_{H}}{1-E_{H}}
$$

In (9), when $E_{H}$ approaches $1, w$ tends to infinity. As $E_{H}$ also depends on the number of hierarchical layers in the structure, for high values of $E_{H}$, the greater the range of possible values for the span of control will be.

\section{INDUSTRY 4.0 IMPACT ON ORGANIZATIONAL MANAGEMENT}

In this chapter, we check for the context of industry 4.0 the three previous conjectures about the effects of specialization, authority, and span of control on manufacturing efficiency.

First, we argue that "specialization is much more important than Ricardo's concept of comparative advantage" [29].

Our position refutes the prevailing view in the economy that has spread to the management of exogenous over endogenous comparative advantages. In part, this fragmentation resulted from the formalization of mathematical modeling in the late 19th century. Simi-larly, Farrell's efficiency has an endogenous con-text limited to an exogenous standard. Organizations do not exist as fully open systems, nor as closed systems. The-refore, organizations must take care of their internal structure and observe and, where possible, influence the outside.

However, economic, social, environmental, and cultural systems are so complex that they allow multiple theories to explain the same reality [29]. Therefore, when industry 4.0 proposes a plethora of CPS with different integration solutions, it cannot guarantee permanent total efficiencies, as they always depend on volatile contexts that will influence the final result.

As an example, table 5 presents the economic effect of different types of the labor force on production in manufacturing. The data do not show a clear relationship between the proportion of skilled workers (of all production workers) and value added per worker.

Table 5. Value added by production workers in several countries.

\begin{tabular}{|c|c|c|c|}
\hline Economy & $\begin{array}{c}E_{H} \\
\text { Proportion of } \\
\text { production workers } \\
\text { (out of all permanent } \\
\text { workers) }(\%)^{1}\end{array}$ & $\begin{array}{c}\text { Proportion of } \\
\text { skilled workers } \\
\text { (out of all } \\
\text { production } \\
\text { workers) }(\%)\end{array}$ & $\begin{array}{c}V_{p w} \\
\text { Value added } \\
\text { per worker } \\
\left(10^{3} \text { current }\right. \\
\text { US\$) })^{2}\end{array}$ \\
\hline 144 countries & 72,1 & 76,8 & \\
\hline $\begin{array}{c}\text { Israel } \\
(2013)\end{array}$ & 55,9 & 88,8 & 60,27 \\
\hline $\begin{array}{c}\text { Sweden } \\
(2014)\end{array}$ & 68,5 & 80,3 & 81,39 \\
\hline $\begin{array}{c}\text { Serbia } \\
(2019)\end{array}$ & 71,7 & 76,2 & 8,31 \\
\hline $\begin{array}{c}\text { Portugal } \\
(2019)\end{array}$ & 74,7 & 89,3 & 23,09 \\
\hline $\begin{array}{c}\text { Ukraine } \\
(2019)\end{array}$ & 72,6 & 82,6 & 8,35 \\
\hline $\begin{array}{c}\text { Luxembourg } \\
(2020)\end{array}$ & 55,8 & 80,33 \\
\hline
\end{tabular}

${ }^{1}$ This indicator was computed by The World Bank [30] using data from manufacturing firms only.

${ }^{2}$ Computed based on data from [31], see (10) and table 6 .

The value added per worker $\left(V_{p w}\right)$ in table 5 arises from the data in table 6 :

$$
V_{p w}=\frac{M_{v a}}{P o p \times L_{f p} \times E m p}
$$

where $M_{v a}$ is the manufacturing value added; Pop is the total population aged 15-64; $L_{f p}$ is the labor force participation rate (\% of total population ages 15-64); and Emp is the employment in industry (\% of total employment).

Table 6. Data to computation of value added per worker.

\begin{tabular}{|c|c|c|c|c|}
\hline Economy & Pop & $\mathrm{L}_{\mathrm{fp}}(\%)^{3}$ & $\operatorname{Emp~(\% )^{3}}$ & $\mathrm{M}_{\mathrm{va}}\left(10^{9}\right.$ current US\$) \\
\hline $\begin{array}{c}\text { Israel } \\
(2013)\end{array}$ & 4956123 & 71,81 & 17,74 & 38,052 \\
\hline $\begin{array}{c}\text { Sweden } \\
(2014)\end{array}$ & 6159447 & 81,53 & 18,60 & 76,021 \\
\hline $\begin{array}{c}\text { Serbia } \\
(2019)\end{array}$ & 4564308 & 67,60 & 27,43 & 7,034 \\
\hline $\begin{array}{c}\text { Portugal } \\
(2019)\end{array}$ & 6623451 & 75,77 & 24,68 & 28,597 \\
\hline $\begin{array}{c}\text { Ukraine } \\
(2019)\end{array}$ & 29896456 & 66,64 & 24,96 & 16,646 \\
\hline $\begin{array}{c}\text { Luxembourg } \\
(2020)\end{array}$ & 442919 & $\begin{array}{c}71,66 \\
(2019)\end{array}$ & $\begin{array}{c}10,81 \\
(2019)\end{array}$ & 2,756 \\
\hline
\end{tabular}

3 modeled ILO (International Labour Organization) estimate

Referring to the base of the organizational pyramid, Ukraine has the highest proportion of skilled workers in the sample (89.4\%). However, it adds an economic value per worker of only US\$3.350. Comparing with Sweden with US\$81.390 per worker, which has a value close to that of skilled workers at the bottom of the hierarchy, the economic value added by Ukraine workers is 24 times lower.

The data show that the advantages of management do not only arise from the skilled workers but stem from human decision flows, which specialization, per se, does not dismiss. According to previous warnings, when adopting industry 4.0 tools, organizations must be aware of the risks arising from the lack or inadequacy of management objectives concerning the organizational context (internal and external). These risks are not technological but systemic.

Although we advocate a concept of specialization that includes diversity, not found in table 5, when using (1) and (3), we must understand the context. Hence, industry 4.0 must integrate a differentiated "smart specialization." According to Foray and Goenaga [32] "Smart specialisation is not a planning doctrine that requires a region to specialize in a particular set of industries. Instead, it seeks robust and transparent means for nominating those new activities, at a regional level, that aim at exploring and discovering new technological and market opportunities and at opening thereby new domains for constructing regional competitive advantages." Despite the apparent opposition to Ricardo's idea of efficiency linked to regional specialization, the proposal of "smart specialization" defends "new domains for the construction of regional competitive advantages." The purpose is reformative, comparative, based on competition, and homothety is ego-centered, i.e., the result comes from the same position (and praxis) but with different tools. 
It may be a consequence of (3) that considers systems contained in mechanical determinism and overestimates machine efficiency and productivity. Such systems do not exist in manufacturing, so technologies, even in industry 4.0, still respond to the purposes of humans and not the other way around.

Thus, in the impossibility of specialization to justify organizational results, we secondly assess whether the attribution of authority can, per se, improve the efficiency of the decision-making process according to (4) and (5).

We have already analytically pointed out that (5) does not verify the effect of synergy on the efficiency of group decision-making. However, even (4) can have adverse results. According to Moscovici and Zavalloni [33], these can be consequences of discussions that result from the polarization of personal opinions. To create an "objective" judgment, group verdicts "will often be adopted by the individuals as their personal opinions." Given this caveat, in the case of multiple interactions in the decision-making process, the result may be the lateralization of Figure 4.

The group's decision is not immune from error and, as described above, can radicalize them. Even in industry 4.0, organizational decisions are still political acts, and groupthink can trigger catastrophic events. One example was the notorious fiasco of the Bay of Pigs invasion [34]. Again, the merits of the preference of a group decision over an individual one depend on human behavior. The concepts in (4) and (5) apply descriptively to sensors, but they require cogitation in social systems.

Third, we examine the span of control on the hierarchy efficiency of organizations. Considering the economic effects, table 5 contradicts the thought that broader control guarantees better results. Luxembourg has one of the highest values added per worker (US\$80.330), despite having the lowest $E_{H}$ value $(55,8 \%)$ of all the values provided by [30]. This circumstance is relevant because it does not invalidate (8), whose assumption is that the number of chiefs is not greater than that of workers.

There are still numerous perspectives on the span of control in organizations, as Figure 7 shows.

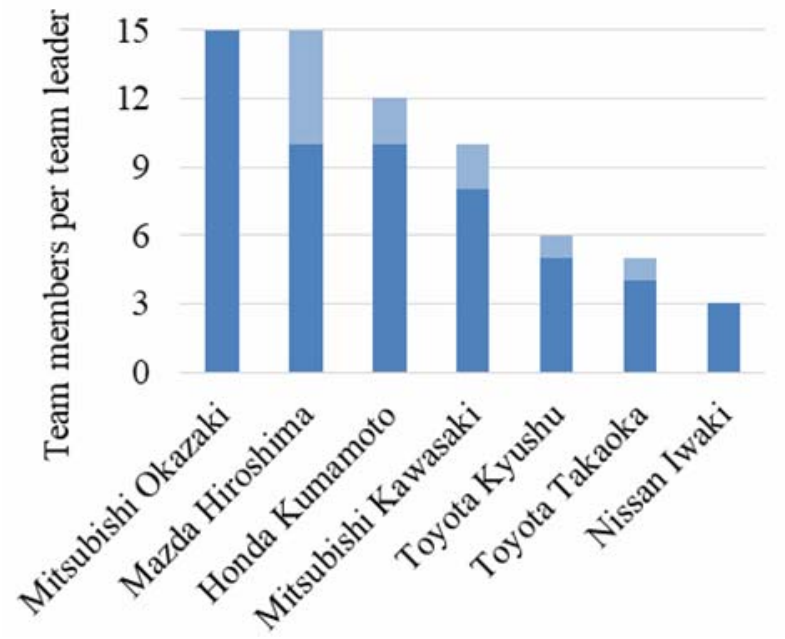

Figure 7: Span of control of several car manufacturers in Japan, adapted from [35].
Japanese companies, namely Toyota, are known for their Lean Thinking. Toyota in the mid-1980s incorporates nine hierarchical layers: Kojochō, Buchō, Jichō, Kachō, Fuku-kachō, Kakarichō, Kumichō, Hanchō, and Shain (shopfloor workers) [36]. The Japanese term chō in English means chief or leader. With eight levels of leadership, each Hanchō leads a few Shain. Considering (8) and $w=5$, we have an $E_{H}$ between $71.4 \%$ and $83.3 \%$.

Graicunas [37] speculated that the increase in the size of teams exponentially and negatively affects communication in organizations. Although Bedeian [38] warns of the introduction of the original Graicunas paper as having an "essentially of a speculative rather than a directly practical nature" character, the Graicunas conjecture is not refuted by (9).

However, just a lower $E_{H}$ value does not ensure better organizational performance. For example, in Table 5, the economic return of Swedish industrial workers, with $E_{H}=68.5 \%$, is higher than that of Luxembourg $\left(E_{H}=55.8 \%\right)$ and Israel $\left(E_{H}=55.9 \%\right)$.

Using $E_{H}$ in Table 5 and (9), we build Table 7.

Table 7. Relationship between $E_{H}$ and span of control for several countries.

\begin{tabular}{|c|c|c|c|}
\cline { 3 - 4 } \multicolumn{2}{c|}{} & \multicolumn{2}{c|}{ Span of Control $(w)$} \\
\hline Countries & $E_{H}(\%)$ & $(\mathrm{min})$ & $(\max )$ \\
\hline All & 72,1 & 2,58 & 5,17 \\
\hline Israel & 55,9 & 1,27 & 2,54 \\
\hline Sweden & 68,5 & 2,17 & 4,35 \\
\hline Serbia & 71,7 & 2,53 & 5,07 \\
\hline Portugal & 74,7 & 2,95 & 5,91 \\
\hline Ukraine & 72,6 & 2,65 & 5,30 \\
\hline Luxembourg & 55,8 & 1,26 & 2,52 \\
\hline
\end{tabular}

The ranges of $w$ fit the smaller values shown in Figure 7. In analyzing the results, we must recognize that they are average values where all companies, small or large, compete. Naturally, large organizations tend to have more hierarchical levels than small ones.

The results ignore that organizations and their political, technological, social, and cultural contexts condition each other. This gap reveals the great challenge that industry 4.0 faces in recognizing the complexity of human behavior in organizations. Even because, according to Taylor [39], management laws are complex, "owing to the fact that the very complex organism - the human being - is being experimented with, are subject to a larger number of exceptions than is the case with laws relating to material things."

\section{CONCLUSION}

The idea of Industry 4.0 arises from a policy with pretensions of dominance through the dissemination of powerful technological tools added to virtual capabilities. However, economic reality, the devaluation of human capabilities valued only by purchasing power, vanity, and the efficiency bias drag most organizations in a flow determined by circumstances. 
The technological inequality that industry 4.0 increases is not a problem for organizations if they do not have a goal and knowledge. Generally, the perversity of organizational results falls on weak leaders because the price of technology today is negligible compared to the inherent knowledge. Industry 4.0 boosts production, competition, and the economy, all of which are undeniably important today. Industry 4.0 can also reduce energy consumption, reduce waste, change and improve communication processes, encourage collaboration or promote social integration, but it always depends on human behavior. The same technology, depending on usage, can achieve different results. Its use, determined by consumption and economic effect, only holds people responsible. The machine helps, but the human decides.

Thus, the concept of industry 4.0 is hostage to choices, the adequacy of its functions to the structures, and subsequent decisions. Organizations are not ephemeral, and the adequate qualification of decisions is essential, even they are technologically developed.

If, on the one hand, perhaps an excessive number of hierarchical levels can explain the inefficiency of communication and the lack of involvement of the organizational model [40], one can also question the model itself, which may be incompatible with the current culture. Industry 4.0's messianic desire to reduce the intended hierarchical levels is not consistent if structural, cultural, transformative, and inclusive changes do coexist.

This paper demonstrated that a holistic and contextually integrated analysis is needed to assess the consequences of adopting Industry 4.0 in organizations. Deterministic simplifications can elude realities and even harm the integration of new resources resulting from technological development in manufacturing systems.

Organizations have not yet abandoned the classic perspectives of economics and management, which emerge with different hypes. Industry 4.0 risks being another missed opportunity to change the organizational paradigm if it only addresses one of the three concepts covered in chapter three in isolation: specialization, authority, and hierarchy efficiency. These, among other internal characteristics of organizations, must be understood by management as intrinsic, economic, social, and culturally relevant.

A limitation of this paper is the use of mean values for hierarchy efficiency in Table 5 and may not adequately distinguish the realities between small and large organizations in terms of the span of control and proportion of skilled workers. However, as shown in Figure 6, even culturally integrated into the same country, Japan, large organizations have a diversity of scope of control (between 3 and 15), which only an understanding of the internal culture of the organizations themselves can unravel.

The data in table 7 confirms that a higher impact on the efficiency of the organizational structure lies in the span of control at the bottom of the hierarchical pyramid.

The change in organizations proposed by Industry 4.0 , based on the CPS, can be made by the tools that will influence human behavior. The objective remains efficiency and production. However, the social purpose is dubious or non-existent. The Industry 4.0 proposal instigates the continuity of the specialization that arose with the first industrial revolution.

Our results demonstrate the impossibility of managing an intervention based only on specialization, decision-making process, or span of control. The system (from ancient Greek $\sigma u ́ \sigma \tau \eta \mu \alpha$ means "organized body composed of several parts or members") must consider the interior and exterior of the organization. Volatile contexts emerge from uncertainty and complex problems.

We demonstrate that the management of Industry 4.0 only promotes the transformation of society if it understands the economy, society, environment, and the culture of organizations with a systemic approach.

\section{ACKNOWLEDGMENT}

This work has been supported by FCT - Fundação para a Ciência e Tecnologia within the R\&D Units Project Scope: UIDB/00319/2020.

\section{REFERENCES}

[1] Pinheiro, P. et al.: Industry 4.0 and industrial revolutions: An assessment based on complexity, FME Transactions, vol. 47, No. 4, pp. 831-840, 2019.

[2] Putnik, G. D., Ferreira, L., Lopes, N. and Putnik, Z.: What is a Cyber-Physical System: Definitions and models spectrum, FME Transactions, vol. 47, No. 4, pp. 663-674, 2019.

[3] Shah, V. and Putnik, G. D.: Machine learning based manufacturing control system for intelligent cyberphysical systems, FME Transactions, vol. 47, No. 4, pp. 802-809, 2019.

[4] Drucker, P. F.: Technology, management, and society: Harvard Business Press, 2011.

[5] Mitleton-Kelly, E.: Ten principles of complexity and enabling infrastructures in Advanced series in management, Complex systems and evolutionary perspectives on organisations: the application of complexity theory to organisations, E. MitletonKelly, Ed., 1st ed., Amsteradm: Pergamon, 2003, pp. 23-50.

[6] Putnik, G. D. and Putnik, Z.: Defining sequential engineering (SeqE), simultaneous engineering (SE), concurrent engineering (CE) and collaborative engineering (ColE): on similarities and differences, Procedia CIRP, vol. 84, pp. 68-75, 2019.

[7] Farrell, M. J.: The measurement of productive efficiency, Journal of the Royal Statistical Society: Series A (General), vol. 120, No. 3, pp. 253-281, 1957.

[8] Ricardo, D.: Principles of political economy and taxation. Kitchener: Batoche Books, 2001.

[9] Drucker, P. F.: The effective executive: Routledge, 2018.

[10]Kopp, R. J.: The measurement of productive efficiency: A reconsideration, The quarterly journal of economics, vol. 96, No. 3, pp. 477-503, 1981. 
[11]Charnes, A., Cooper, W. W. and Rhodes, E.: Measuring the efficiency of decision making units, European journal of operational research, vol. 2, No. 6, pp. 429-444, 1978.

[12] Cook, W. D. and Seiford, L. M.: Data envelopment analysis (DEA)-Thirty years on, European journal of operational research, vol. 192, No. 1, pp. 1-17, 2009.

[13]Li, W., Cook, W. D., Li, Z. and Zhu, J.: Efficiency measurement for hierarchical situations, Journal of the Operational Research Society, vol. 72, No. 3, pp. 654-662, 2021.

[14] Martin, R. L.: The high price of efficiency, Harvard business review, vol. 97, No. 1, pp. 42-55, 2019.

[15] Ellram, L. M., Tate, W. L. and Feitzinger, E. G.: Factor market rivalry and competition for supply chain resources, Journal of Supply Chain Management, vol. 49, No. 1, pp. 29-46, 2013.

[16]Lu, C., Zhu, H., Yao, Y., Nian, X. and Fan, X.: Analysis of the Mask Price Change from the Perspective of Economics, Financial Forum, vol. 9, No. 4, pp. 185-190, 2021.

[17] Pattee, H. H.: The physical basis and origin of hierarchical control, Hierarchy theory, pp. 73-108, 1973.

[18] Skelcher, C.: Hybridity in vol. 1, Encyclopedia of Governance, M. Bevir, Ed., Thousand Oaks: Sage, 2007, p. 432.

[19] Potochnik, A. and McGill, B.: The limitations of hierarchical organization, Philosophy of Science, vol. 79, No. 1, pp. 120-140, 2012.

[20] Enaleev, A. K. and Tsyganov, V. V.: Alignment of cluster complexity at network systems, FME Transactions, vol. 47, No. 4, pp. 711-722, 2019.

[21] Simon, H. A.: The proverbs of administration, Public administration review, vol. 6, No. 1, pp. 5367, 1946.

[22] Fayol, H.: General and Industrial Management. "Administration Industrielle et Générale: prévoyance, organisation, commandement, coordination, contrôle", 3rd ed. Paris: Dunod, 1917.

[23] Whyte, W. H.: The Organization Man. Philadelphia: University of Pennsylvania Press, 2002.

[24] Tsyganov, V. V.: Adaptive identification of innovative production function of corporation, FME Transactions, vol. 47, No. 4, pp. 691-698, 2019.

[25] Taylor, F. W.: Shop Management. New York: Harper \& Brothers, 1911.

[26] Bloch, A.: Murphy's Law and other reasons why things go wrong! New York: Price/Stern/Sloan, 1977.

[27] Crumley, C. L.: Heterarchy and the analysis of complex societies, Archeological Papers of the American Anthropological Association, vol. 6, No. 1, pp. 1-5, 1995.

[28] Popovic, N., Putnik, G. D., Jasko, O. and Filipovic, J.: A contribution for a pragmatics-based approach to concurrent engineering implementation /Prispevek k pragmaticnemu pristopu do uvajanja socasnega inzenirstva, Strojniški vestnik - Journal of Mechanical Engineering, vol. 59, No. 7-8, pp. 483-496, 2013.

[29] Yang, X. and Ng, Y.-K.: Specialization and Economic Organization: A New Classical Microeconomic Framework. Amsterdan: NorthHolland, 1993.

[30] The World Bank: Enterprise Surveys. [Online] Available: http://www.enterprisesurveys.org. Accessed on: Aug. 102021.

[31] The World Bank: World Bank Open Data: Free and open access to global development data. [Online] Available: https://data.worldbank.org. Accessed on: Aug. 102021.

[32]Foray, D. and Goenaga, X.: The goals of smart specialisation. Seville: Luxembourg: Publications Office of the European Union, 2013.

[33] Moscovici, S. and Zavalloni, M.: The group as a polarizer of attitudes, Journal of personality and social psychology, vol. 12, No. 2, p. 125, 1969.

[34] Janis, I. L.: Victims of Groupthink: A psychological study of foreign-policy decisions and fiascoes. Boston: Houghton Mifflin, 1972.

[35] C. Roser: The Grand Tour of Japanese Automotive - Overview and Toyota. [Online] Available: https://www.allaboutlean.com/grand-touroverview-and-toyota/. Accessed on: Aug. 102021.

[36]Benders, J. and van Bijsterveld, M.: Leaning on lean: The reception of a management fashion in Germany, New Technology, Work and Employment, vol. 15, No. 1, pp. 50-64, 2000.

[37] Graicunas, V. A.: Relationship in Organization in Papers on the Science of Administration, L. Gulick and L. Urwick, Eds., New York: Columbia University, 1937, pp. 183-187.

[38]Bedeian, A.: Relationship in Organization: A Clarification, Academy of Management Journal, vol. 15, No. 2, pp. 238-239, 1972.

[39] Taylor, F. W.: The Principles of Scientific Management. New York: Harper \& Brothers, 1913.

[40] Vicente, S., Alves, A. C., Carvalho, S. M. and Costa, N.: Business sustainability through employees involvement: A case study, FME Transactions, vol. 43, No. 4, pp. 362-369, 2015.

\section{ИЗГЛЕДИ ЗА ОРГАНИЗАЦИОНУ ЕФИКАС- НОСТ ЗА МЕНАҢМЕНТ У ИНДУСТРИЈИ 4.0}

\section{П. Пињеиро, Г. Путник}

Индустрија 4.0 се јавља као алат који помаже организацијама да управљају. Често се поистовећује са интернетом ствари и сајбер-физичким системима, Индустрија 4.0 се појављује као решење за многе потешкоће које муче производњу. Историја теорија управљања, нпр. аутора Тејлор, Фајол или Симон, 
показује да детерминистичка решења не обезбеђују трајни успех организација. У производњи, економиja ce преклапа са технолошким, друштвеним, еколошким и културним димензијама које утичу на организације.

У овом раду се оцењују могуће користи за ефикасност организација које проистичу из примене Индустрије 4.0. У ову сврху, истражују се ефекти на хијерархијске структуре организација, наиме они који се односе на специјализацију, ауторитет и распон контроле.

Резултати показују да технолошки напредак и ефикасност индустрије 4.0, који су релевантни за економију, и даље не одговарају задовољавајуће друштвеним потребама које захтевају промене у понашању система управљања. 